\title{
ALASAN ORANG SUKA BUAH MELON
}

\author{
Akhmad Fauzi Afandi \\ Universitas Nahdlatul Ulama Sidoarjo \\ Email: akhmad.islam.surga@gmail.com
}

\begin{abstract}
Melon sangat di cintai masyarakat karena rasanya enak dan mempunyai kandungan gizi yang tinggi diantaranya adalah vitamin dan mineral yang diperlukan manusia. Selain mempunyai kandungan gizi, melon juga mempunyai nilai ekonomi yang cukup tinggi. Zuliana(2015) mengatakan melon (Cucumismelo L.)Tergolong tanaman semusim yang tumbuh merambat berbatang lunak, dari setiap pangkal tangkai daun pada batang utama tumbuh tunas lateral. Pada tunas lateral ini lah muncul bunga betina (bakal buah) yang rata-rata mampu menghasilkan 1-2 calon buah. Namun tidak semuanya menjadi buah. Calon buah yang tidak sempat diserbuk ia kan gugur. Untuk itu, kegiatan perempelan tunas lateral harus dilakukan kecuali pada tunas lateral yang bakal buahnya akan dijadikan buah.
\end{abstract}


Buah melon berbentuk bulat, SUNPRIDE Indonesia (2016) Bagian yang dimakan dari buah Melon ini adalah daging buah (mesokarp). Teksturnya lunak, berwarna putih sampai merah, tergantung kultivarnya.Sunpride sendiri memiliki 3 jenis melon, yaitu Rock Melon (Daging buah berwarna orange, berbentuk bulat hamper seragam dengan kulit bertekstur), Honey Melon (Daging berwarna hijau muda tebal, kulit berwarna putih mengkilat dengan permukaan halus) dan Golden Melon (Daging berwarna putih, dengan kulit berwarna kuning cerah).

Melon bisa diproduksi dengan hidroponik. Hidroponik sistem terapung non sirkulasi sudah berhasil diaplikasikan pada tanaman sayur. Kebutuhan oksigen bagi perakaran pada kultur air dapat dipenuhi dengan cara paling sedikit $1 / 3-1 / 2$ sistem perakaran tidak terendam larutan nutrisi (Maghfoer, Wardiyati, \& Purnomo, 2007). Bentuk bulat alami buah - buahan bukanlah bentuk yang paling efisien dalam urusan logistik. karena sulit ditumpuk, dapat menggelinding dan sisa ruang / celah antara buah (Purnomo, \& Rosyidah, 2010). 
Dengan tidak ada sudut di tepi nya atau melingkar, Sugeng (2016) mengatakan ini adalah jenis buah yang memiliki bentuk melingkar untuk sedikit lonjong, dan biasanya sekitar 15 sampai $22 \mathrm{~cm}$ diameter.

Kesan pertama melihat melon enak di pandang karena mudah di bawa ke manamana dan bentuknya tidak terlalu besar dan tidak terlalu kecil. Lestari(2015) mengatakan melon termasuk buah yang mudah didapatkan di pasaran. Meski melon adalah sebutan untuk satu buah, tapi jenis melon ternyata beragam.Setidaknya ada tiga jenis melon yang bisa anda temui di pasar.

Buah melon memiliki rasa manis. Penulis (2016) mengatakan rasa buah melon yang manismerupakanfaktor yang harus diperhatikan agar nilai jual buah melon yang dihasilkan meningkat. Rasa manis pada buah melon merupakan kombinasi dari berbagai faktor yang terkait dengan pengisian karbohidrat pada buah secara optimum serta konversi karbohidrat menjadi gula yang sempurna sehingga konsentrasi gula dalam cairan sel meningkat.

Lezat dan apalagi di buat olahan es buah melon di musim panas makin terasa segar buah melonnya. Orang Indonesia 
sangat suka sekali dengan buah melon karena mudah sekali mengolahnya maupun di makan langsung. Abdurahim(2017) mengatakan buah ini tidak kalah menyegarkan dengan buah lainnya. Rasanya juga enak dan manis, ditambahkan kedalam salad akan menjadi satu kombinasi yang lebih lezat.

Warna buah melon yang sudah matang berwarna hijau, warna yang sangat mudah di ingat dan hampir semua orang tau tentang warna buah melon ini. Penulis (2016) mengatakan melon ini biasa juga disebut dengan musk melon, sky rocket, atau melon lokal. Kulitnya tebal dan kasar serta bertekstur seperti jala. Buahnya sendiri punya aroma yang sangat harum dan rasanya manis. Melon hijau punya kandungan vitamin $\mathrm{C}$ yang tinggi. Kandungan ini dipercaya bisa meningkatkan kandungan kolagen dalam kulit sehingga mencegah penuaan dini.

Hijau juga itu warna kesukaan saya sehingga menambah kesan favorit pada buah tersebut. Admin(2016) mengatakan dari sisi psikologi warna ini menggambarkan dalam diri seseorang melambangkan adanya satu keinginan yang kuat, ketabahan dalam menghadapi persoalan hidup, memiliki kepribadian yang keras serta lambing keberkuasaan. Salah satu ahli psikologi dari 
Belanda mengatakan bahwa warna memiliki pengaruh yang sangat besar bagimanusia yang dimana meliputi kejiwaan, semangat serta vitalitas, kebahagiaan, kenyamanan diri yang akhirnya berpengaruh pada bagaimana seseorang menyikapi kehidupan. Sedangkan menurut para pakar psikologi hijau adalah warna yang bisa membangkitkan kebahagiaan, rasa gembira, serta gairah hidup. Oleh karena itu corak ini banyak diaplikasikan pada kamar rumah sakit, ruang operasi bahkan pakaian para ahli bedah pun menggunakan warna yang satu ini. Warna ini memang memberikan sifat menyegarkan, membangkitkan energy diri, membawa ketenangan, menyeimbangkan emosi, meningkatkan rasa bangga pada personalnya.

Buah melon sangat banyak digemari masyarakat Indonesia bahkan sudah mendunia, ini dapat diketahui dengan banyaknya permintaan pasokan buah melon ini kemancanegara. Untuk dapat menghasilkan buah melon yang sesuai dengan permintaan pasar baik jumlah maupun kualitasnya perlu budi daya yang baik. Budi daya tanaman melon yang baik akan menghasilkan buah yang maksimal jumlah dan kualitasnya. Budi daya buah melon harus di tempatkan di tempat yang di sediakan, dan sudah dibersihkan secara steril terlebih 
dahulu, agar tanaman yang akan di tanam tumbuh dengan baik dan terhindar dari hama maupun penyakit lainnya. Hidroponik berasal dari kata hydro yang berarti air dan Phonic yang berarti pengerjaan. Sehingga secara umum pengertian hidroponik yaitu sistem budidaya pada pertanian tanpa menggunakan tanah liat sebagai bahan menanam, tetapi menggunakan air yang bercampur larutan nutrient sebagai bahan untuk menanam (Munjidah et al., 2018).

\section{References}

Abdurahim, E. S. (2017). Enak dan Sehat! Ini 10 Buah yang Cocok Dipadu dengan Salad. Retrieved April 18, 2018, from https://food.detik.com/info-sehat/d3764323/enak-dan-sehat-ini-10-buahyang-cocok-dipadu-dengan-salad-1

Admin. (2016). Memaknai Arti Warna Hijau Secara Filosofi dan Psikologi. Retrieved April 18, 2018, from http://toriolo.com/artiwarna-hijau/

Lestari, D. S. (2015). Tiga Jenis Melon yang Populer di Indonesia. Retrieved April 17, 2018, from https://lifestyle.okezone.com/read/2015/08 /13/298/1195481/tiga-jenis-melon-yang- 
populer-di-indonesia

Maghfoer, M. D., Wardiyati, T., \& Purnomo, A. (2007). Pengaturan Jarak Panel dengan Permukaan Media pada Teknik Hidroponik Sistem Terapung Tanaman Melon. Agrivita, 9 (Khusus), 388-396.

Munjidah, A., Nahdiyah, K., Maula, I., Asitah, N., Yuniarti, D., Sholichah, S. A., Purnomo, A., Rosyidah, E., Fidiana, W., Anam, F., Achmadi, A. K. (2018, May 27). Hidroponik: 5 Premis Rekognisi Bagi Pemula.

http://doi.org/10.17605/OSF.IO/HJRQP

Penulis. (2016a). 6 Jenis Buah Melon yang Perlu Anda Tahu. Retrieved April 18, 2018, from

https://resepkoki.id/2016/08/08/6-jenisbuah-melon-yang-perlu-anda-tahu/

Penulis. (2016b). Teknik Membuat Rasa Buah Melon Lebih Manis. Retrieved April 17, 2018, from

http://www.tanamanku.net/teknikmembuat-rasa-buah-melon-lebihmanis.html

Purnomo, A., \& Rosyidah, E. (2010). Rumah Kotak Tumbuh bagi Keluarga Semangka. In 102 Inovasi Indonesia. Jakarta: 
Business Innovation Center.

Sugeng, M. (2016). Manfaat Buah Melon Madu. Retrieved April 17, 2018, from http://tipscaramanfaat.blogspot.co.id/2016 /03/manfaat-buah-melon-madu.html

SUNPRIDE Indonesia. (2016). Melon, Si Bulat Yang Bikin Awet Muda. Retrieved April 17, 2018, from http://www.sunpride.co.id/2016/04/20/mel on-si-bulat-yang-bikin-awet-muda/\#

Zuliana, R. (2015). Artikel Tentang Melon. Retrieved April 17, 2018, from https://zuliana12.wordpress.com/2015/06/ 16/artikel-tentang-melon/ 